\title{
Aquatic vascular plants of South Brazil: checklist and a comparative floristic approach
}

\author{
Lukiel dos Santos Oliveira ${ }^{1}$ (D, Bianca Ott Andrade ${ }^{2}$ (i), llsi lob Boldrini ${ }^{3}$ (i) and Maria Cecilia de Chiara Moço ${ }^{3 *}$ (i)
}

Received: June 4, 2019

Accepted: June 16, 2019

\begin{abstract}
Aquatic ecosystems support species diversity, and knowledge of plant communities is essential for wetland conservation programs. This study provides a checklist of aquatic vascular plants of South Brazil and establishes their floristic affinities with bordering South America phytogeographical domains. The checklist was based on 52 sources, including 35 floristic lists, 17 regional taxonomic studies, and information from an electronic database on wetlands of South Brazil. Floristic similarities with published checklists for neighbouring regions were assessed. A total of 780 species distributed in 277 genera and 85 families of vascular plants were reported for South Brazil. Families with higher species richness were Cyperaceae (128), Poaceae (102), Asteraceae (69), Plantaginaceae (21), Lentibulariaceae (20), and Onagraceae (20). The most represented genera were Eleocharis (41) and Cyperus (24). A cluster analysis revealed high similarity with Iberá (Argentinian Chaco), Pampa and Atlantic Forest, and low similarity with Pantanal, Caatinga and the Amazon Rainforest. The high number of aquatic plant families recorded relative to temperate and tropical climates suggests a zone of biogeographical overlap in Southern Brazil. The compiled data set reveals high biodiversity of wetlands of South Brazil, provides a baseline for future research, and highlights the need for regional conservation planning.
\end{abstract}

Keywords: floristic, macrophyte distribution, plant diversity, species diversity, wetland conservation

\section{Introduction}

Wetlands are estimated to comprise $20 \%$ of the Brazilian territory (Neiff 2001; Junk et al. 2014). Hydrographic basins of Paraná, Uruguay River and southeast and south coast basins compose the hydrography of South Brazil. Paraná and Uruguay Rivers present an important network of tributaries, a critical component of particular interest regarding water source, energy, and tourism. The south coast basin includes the basin of the Guaíba river with its tributaries that end in the Patos Lagoon. This lagoon is the largest choked lagoon in the world, with an area of $10,227 \mathrm{~km}^{2}$ (Asmus 1998).
The coastal plain of Rio Grande do Sul consists of a coastal lake system shaped during Pleistocene and Holocene sea transgression and regression phases (Asmus 1998). This region has more than 60 freshwater or brackish water lagoons, in addition to estuaries and floodplains.

Many authors have proposed different criteria for classifying wetlands to characterize particularities of each region (Zoltai et al. 1975; Cowardin et al. 1979; Brinson 1993; Pressey \& Adam 1995). Maltchik et al. (2004) proposed a hierarchical classification of wetlands for the state of Rio Grande do Sul, with emphasis on the structure of plant communities, while avoiding regional terms. Simillarly, Junk et al. (2011) classified the Amazonian inland wetlands

1 Programa de Pós-Graduação em Botânica, Universidade Federal do Rio Grande do Sul, 91501-970, Porto Alegre, RS, Brazil

2 Department of Agronomy and Horticulture, University of Nebraska-Lincoln, 68583-0915, Lincoln, NE, USA

3 Departamento de Botânica, Universidade Federal do Rio Grande do Sul, 91501-970, Porto Alegre, RS, Brazil

* Corresponding author: mcecilia.moco@ufrgs.br 
based on the structure of plant community. Recently, several researchers from different regions of Brazil gathered to draw up a preliminary national classification of wetlands (Junk et al. 2014), highlighting the importance of wetland inventories for governements to subsidize national policy regarding management and protection of wetlands.

This study is part of a national initiative aiming to provide a Brazilian checklist for wetland ecosystems. Subsets for the north and northeast (Moura Júnior et al. 2013; 2015) and, more recently, the southeast (Pivari et al. 2018) have been already been published. Thus, in this study, we addressed the following questions: (I) how many species are recorded in South Brazil? (II) How strong are the floristic links between wetlands of South Brazil (Pampa and Atlantic Forest) and other South American wetland regions such as Pantanal, Caatinga, Amazon Rainforest, and Argentinian Chaco? For this, we compiled the available floristic data of aquatic vascular plants of South Brazil wetlands, evaluated species distribution patterns within South Brazil wetlands and their floristic affinities with wetlands of neighbouring South American phytogeographical domains.

\section{Materials and methods}

Study area

Our study area was comprised of wetland ecosystems in South Brazil, which includes the states of Paraná (PR), Santa Catarina (SC), and Rio Grande do Sul (RS). This region presents two phytogeographic domains: Atlantic Forest and Pampa. The Atlantic Forest occupies the eastern slopes and valleys of the South Brazilian plateau, from the northeast part of Rio Grande do Sul to the coastal plain, and the highland slopes of the states of Santa Catarina and Paraná (Overbeck et al. 2007). Different forest types occur in distinct climatic conditions; grasslands form isolated patches within this forested landscape (Andrade et al. 2016). The Pampa occupies the southern half of Rio Grande do Sul, extending beyond Brazilian boundaries to Uruguay and center-east Argentina, regiong that is regionally known as Río de la Plata grasslands. In this domain, the predominant vegetation is natural grassland that covers extensive areas. Forests are mostly restricted to riversides.

\section{Aquatic plant definition}

In this study, we followed the aquatic vascular plant definitions by Cook et al. (1974); plants with photosynthetically active parts permanently or for several months of the year, totally or partially submersed in freshwater, or floating in aquatic habitats. This definition takes into consideration the complexity of different environmental factors that determine species' presence, especially regarding species that extend over a wide range of habitats with different water availability.

\section{Data source and methods}

We compiled species data of published and gray literature on South Brazil 'aquatic plants' and equivalent terms, published between the 1984 and 2015. We consulted books, national and international scientific papers, and Ph.D. and master's theses containing lists of vascular plants in South Brazil. Additional information was gathered from taxonomic studies of selected plant families containing aquatic plants, and from the electronic data set of the Brazil Flora Group (BFG 2015), which is still being compiled. We filtered records of species by region, phytogeographical domain (i.e. Pampa and Atlantic Forest), and aquatic plant type.

We selected the studies in which (i) all recorded species were classified by life forms and indicated as aquatic plants by authors, or (ii) the environment was classified as wetland. In case of unreliable occurrence, the species was not considered.

Our data included 35 floristic lists and 17 taxonomic studies, totalling 52 consulted sources (as seen in List S1 in supplementary material). From these 52 sources, 34 had geographic coordinates, while the remaining sources were taxonomic studies or general floristic lists regarding a broader region (Fig. 1). We decided to present the results according to political boundaries, hoping to stimulate new research studies in areas with little or no studies within South Brazil.

We used aquatic plants checklists of other Brazilian phytogeographical domains as Caatinga (Moura Júnior et al. 2013), Pantanal (Pott \& Pott 1997) and Amazon Rainforest (Moura Júnior et al. 2015) to evaluate the floristic similarity with neighbouring regions. We also included the Argentinian area "Iberá wetlands" from the Argentinian Chaco (Arbo et al. 2002) as neighbouring region. No data set or checklist of aquatic plants of the Cerrado domain was available. However, Pantanal and Cerrado belong to the same phytoecological domain, according to Pott et al. (2011) and Cunha et al. (2016).

After data compilation, we checked nomenclature and taxonomy of the South Brazilian species list, using the Missouri Botanical Gardens' Tropicos website (http://www. tropicos.org); family classification followed the APG IV systems (2016) for angiosperms, and Smith et al. (2008) for ferns. Exotic species, infraspecific taxa or non-confirmed taxonomic entities (92 taxa) were excluded from the analysis. Distribution of plant species reported for Rio Grande do Sul was confirmed with the Global Biodiversity Information Facility (GBIF http://www.gbif.org) and Species Link (http:// splink.cria.org.br/), since two phytogeographical domains (Pampa and Atlantic Forest) are found in this state.

\section{Data analysis}

A total of 1423 species of South Brazil and other regions of South America were compiled. To evaluate vegetation 


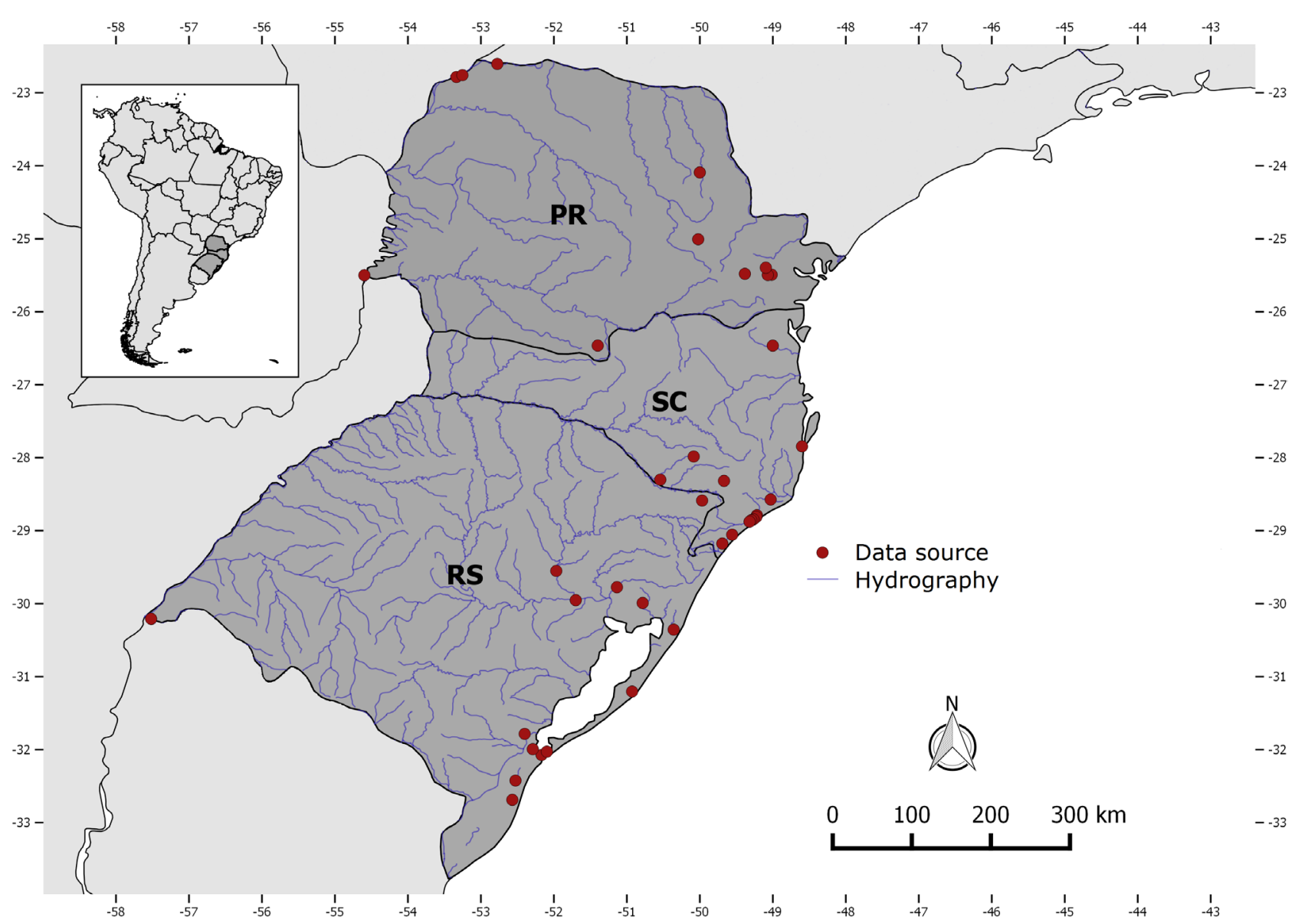

Figure 1. Location map of all sites with available geographical location along the Southern Brazilian region (in red). PR = State of Paraná; SC = State of Santa Catarina; RS = State of Rio Grande do Sul.

similarity among different sources, we used a binary matrix with presence (1) and absence (0) of species. Thereafter, we conducted an agglomerative hierarchical clustering analysis (Legendre \& Legendre 2012) for results presentation and interpretation. Similar sites were clustered and aggregated into larger and larger clusters to form a single cluster containing all sites (Roleček et al. 2009). This analysis was performed using UPGMA (average linkage) and Sørensen dissimilarity, using vegan package (Oksanen et al. 2013) in R (R Development Core Team 2013). Sørensen's coefficient quantifies the dissimilarity in species composition, i.e. values close to 0 (zero) indicate little species correlation, while values close to 1 (one) indicate almost identical species composition (high similarity).

\section{Results}

The final list included 760 aquatic plant species of South Brazil (Tab. S1 in supplementary material), distributed in 281 genera and 84 families. Some species (207) were found in more than one data set. Floristic studies accounted for 414 species of the list, while taxonomic studies acounted for 31 species. A total of 108 species were only recorded in the filterd selection of the Flora do Brasil website (BFG 2015). The most representated families were Cyperaceae (126), Poaceae (99), Asteraceae (66), Plantaginaceae (20), Lentibulariaceae (20), Onagraceae (20), Rubiaceae (18), Fabaceae (18), Eriocaulaceae (17), and Xyridaceae (17), comprising $55 \%$ of all species in this region. Twenty-six families (3\% of all plant species) were represented by only one species. The most representated genera were Eleocharis and Cyperus, with 41 and 23 species, respectively.

Floristic studies were unequally distributed among the states of South Brazil. Most studies were conducted in the state of Rio Grande do Sul (RS; 57\%), followed by Paraná (PR; $29 \%$ ) and Santa Catarina (SC; $14 \%$ ). The species richness followed the same pattern, with 555, 444, and 395 species respectively.

Regarding phytogeographical domains in South Brazil, $9 \%$ of all species were restricted to the Pampa, $42 \%$ to the Atlantic Forest, and the remaining $49 \%$ occurred in both, with a wide range of distribution.

Regarding the frequency of occurrence, $43 \%$ of species were recorded in only one source, $50 \%$ were reported in $2-10$ sources, and $6 \%$ were recorded in $11-19$ sources. Less than $1 \%$ of species were recorded in 20 or more sources, such as Hydrocotyle ranunculoides, Nymphoides humboldtiana, 
Myriophyllum aquaticum, Polygonum punctatum, Polygonum hydropiperoides, Typha domingensis, Eichhornia azurea and Pontederia cordata.

The phytogeographical domains in descending order of species richness were Atlantic Forest (only Southern region) (693 spp.), Amazon Rainforest (513), Pampa (442), Caatinga (372), Argentinian Chaco (349), and Pantanal (220). The cluster analysis based on Sørensen's index supported the distinction of two groups among all phytogeographic domains (Fig. 2). The first group was formed by Amazon Rainforest, Pantanal and Caatinga, with only 55 shared species, and low indices of similarity.

In the second group, the Argentinian Chaco was clustered with two other subgroups, one composed of Pampa and Atlantic Forest RS (28\% dissimilarity), and another formed by Atlantic Forest SC and Atlantic Forest PR (36\% dissimilarity). Pampa and Atlantic Forest RS presented the highest similarity.
From the total compiled 1423 species, 26 species occurred in all domains (Tab. S1 in supplementary material), while 815 (57\%) had exclusive occurrence.

\section{Discussion}

We compiled a high number of aquatic plants (760 species) in wetlands of South Brazil from literature records. The recorded number of 555 species in RS confirmed a previous estimation by Irgang \& Gastal (1996) of 400 to 500 species for the coast of Rio Grande do Sul alone. According to these authors, this number is explained by the variation of aquatic environment factors, such as light, temperature, substrate, nutrient content, and water flow act as habitat filters that may influence species' distribution and abundance across the landscape (Poff 1997; Shi et al. 2010). The habitat heterogeneity hypothesis assumes a correlation between area and its number of different habitats, and
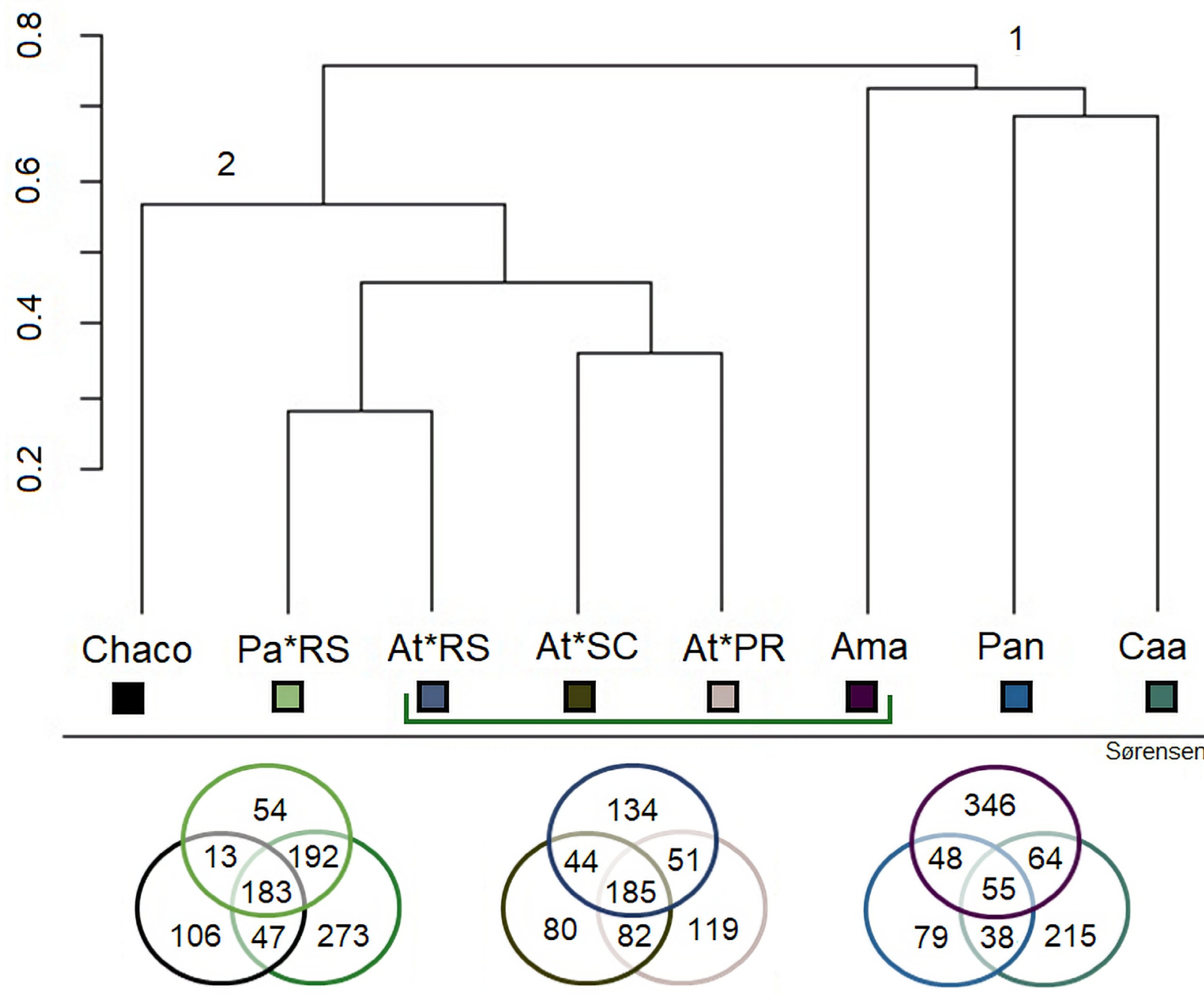

Figure 2. Dendrogram produced by group averaging Sørensen's index presenting floristic similarity for species of the eight regions. Each colour represents a domain or region and the dissimilarity coefficients are between 0.2 and 0.8 . The Venn diagrams show the regions and the number of restricted and shared species. Pa*RS = Pampa RS; At*RS = Atlantic Forest RS; At*SC = Atlantic Forest SC; At ${ }^{*} \mathrm{PR}=$ Atlantic Forest PR; Chaco = Iberá wetlands Argentina; Ama = Amazon Rainforest; Pan = Pantanal; Caa = Caatinga. 
also assumes that different habitats host a different array of species (Williams 1964; Drakou et al. 2009). The total number of species recorded in South Brazil was higher than in other regions in Brazil, even when comparing Atlantic Forest and Pampa individually. It is possible that the aquatic plant diversity in South Brazil is a result of the large variability of habitats in the region (e.g. lakes, wet grasslands, lagoons, floodplains, marshes).

Out of the total, $43 \%$ of species were registered in only one source. This was due to a restricted geographical distribution of some species that were only recorded in taxonomic works, while many other recorded species were present in habitats with difficult delimitation. This occurs because a variety of plants exhibit plasticity in response to water dynamics. It is difficult to establish a limit between aquatic and terrestrial plants, and thus, to determine the thresholds of a wetland (Lavania et al. 1990; Barrett et al. 1993; Crow \& Hellquist 2000).

Cyperaceae and Poaceae were the families with the highest numbers of species in the wetlands of South Brazil, similarly to checklists of other regions (Keddy 2000; Sieben et al. 2010). The high occurrence of these families is probably explained by the success in dispersion of sexual propagules (Santamaría 2002) and ubiquitous distribution of species with relevant morphological charachteristics that allow them to spread vegetatively (e.g. rhizomes, tubers and stolons; Goetghebeur 1998).

Cyperaceae has the greatest diversity in humid and semihumid tropics (León et al. 1996; Goetghebeur 1998; Ritter 2004; Kutschker et al. 2014), being Eleocharis and Cyperus the most species-rich of Cyperaceae in Brazil (Alves et al. 2009; Govaerts et al. 2016).

The 26 species that occurred in all phytogeographical domains, (e.g. Eichhornia crassipes, Pistia stratiotes, Hymenachne amplexicaulis and Echinochloa polystachya) are distributed worldwide and are even considered invasive in some regions (Foxcroft et al. 2013). Although a high number of species was shown to have wide distribution not restricted to a single domain (609 spp.), the number of species with exclusive occurrence was almost $30 \%$ higher (814 spp.). This high number may reflect the limits of species distribution by both the climatic differences of tropical and temperate zones throughout the country, and the reproductive restrictions and specific environmental conditions. Although many aquatic plants grow in a broad range of climatic regions, their distribution reflects this zonation to some extent (Santamaría 2002). Differences can be observed at the species and genera level, but are more easily seen at the the family level. For instance, in a study addressing latitudinal patterns in aquatic angiosperms, Crow (1993) highlighted some families with strong tropical affinities (e.g. Hydrocharitaceae, Limnocharitaceae, Mayacaceae, Nymphaeaceae, Podostemaceae, Eriocaulaceae, Pontederiaceae, Xyridaceae), families with temperate affinities (e.g. Potamogetonaceae, Juncaginaceae,
Haloragaceae and Elatinaceae), and families well represented in both latitudes (e.g. Lentibulariaceae). Furthermore, some tropical families are among the families with the highest number of species (Xyridaceae, Lentibulariaceae and Eriocaulaceae). Families with temperate affinities (like Juncaginaceae, Juncaceae and Potamogetonaceae) are represented by only a few species in Brazil; however, the distribution of the clear majority is restricted to the south.

The transitional zone between tropical and temperate climates in South Brazil can explain the high number of families with tropical affinities; the temperate family with distribution restricted to the south region of Brazil, and the high species richness. From an evolutionary point of view, transition zones deserve special attention because they represent areas of intense biotic interaction (Morrone 2009). Its importance highlights the need for conservation approaches in these regions.

The cluster analysis based on wetland species revealed distinct distribution patterns among domains. Group 1 had low similarity, and was composed of Amazon Rainforest, Pantanal, and Caatinga. This cluster's composition is in agreement, in part, with previous studies wherein the north and northeast regions were grouped together (Moura Júnior et al. 2015; Ferreira et al. 2011). However, in the same studies, Pantanal was grouped with the Paraná River floodplain. To clarify this issue, other wetlands besides the ones in Paraná River, state of Paraná were included. Consequently, this state may have been grouped with Santa Catarina, as the Atlantic Forest encompasses both states.

The low similarities suggest floristic particularities among Amazon Rainforest, Pantanal and Caatinga. The Pantanal is often called "pantanal complex" due to its plant mosaic with elements of the major nearby vegetation types: Cerrado, Chaco and Amazon Rainforest (Prance \& Schaller 1982; Cunha et al. 2007). Hence, we recommend grouping the domains Pantanal and Cerrado in future analyses regarding flora. The floristic particularities associated with the Amazon Rainforest have been previously reported by Junk (1986), who demonstrated that few aquatic plants are adapted to the extreme hydrological conditions of the region and are unable to disperse over long distances.

Group 2 included South Brazilian domains/regions with Iberá (Argentinian Chaco). This is not surprising given the high number of shared species and geographical proximity. Overall, this result is in accordance with the study of Morrone (2014) in which the Pampa domain was related with the Chaco domain, and also with the assumption of Irgang \& Gastal (1996) that Uruguay, Argentina, Paraguay and South Brazil form a phytogeographic unit regarding aquatic plants.

An unexpected diversity of macrophytes of South Brazil was shown herein. The number of species will likely increase as new species are discovered, taxonomic revisions are undertaken, and new inventories are conducted in the region. 


\section{Acknowledgements}

We would like to thank CNPq for the scholarship granted to the first author and the financial support to Coordenação de Aperfeiçoamento de Pessoal de Nível Superior - Brasil (CAPES) - Finance Code 001. BOA received a PNPD scholarship through the UFRGS Graduate Program in Botany. Our thanks to Cheryl Dunn for reviewing the manuscript.

\section{References}

Alves M, Araújo AC, Prata AP, et al. 2009. Diversity of Cyperaceae in Brazil. Rodriguésia 60: 771-782.

Andrade BO, Bonilha CL, Ferreira PMA, Boldrini II, Overbeck GE. 2016. Highland grasslands at the southern tip of the Atlantic Forest Biome: management options and conservation challenges. Oecologia Australis 20: 37-61.

APG IV. 2016. An update of the Angiosperm Phylogeny Group classification for the orders and families of flowering plants: APG IV. Botanical Journal of the Linnean Society 181: 1-20.

Arbo MM, López MG, Schinini A, Pieszko G. 2002. Las plantas hidrófilas, acuáticas, de embalsado y palustres. In: Arbo MM, Tressens SG. (eds.) Flora del Iberá. Corrientes, Editorial Universitaria de la Universidad Nacional del Nordeste. p. 9-110.

Asmus ML. 1998. A planície costeira e a Lagoa dos Patos. In: Seelinder U, Odebrecht C, Castello JP. (eds.) Os ecossistemas costeiro e marinho do extremo sul do Brasil. Rio Grande, Ecoscientia. p. 341.

Barrett SC, Eckert CG, Husband BC. 1993. Evolutionary processes in aquatic plant populations. Aquatic Botany 44: 105-145.

BFG. 2015. Growing knowledge: an overview of seed plant diversity in Brazil. Rodriguésia 66: 1085-1113.

Brinson MM. 1993. A hydrogeomorphic classification for wetlands. Technical Report WRP-DE-4. Vicksburg, US Army Corps of Engineers Waterways Experiment Station.

Cook CD, Gut BJ, Rix EM, Schneller J. 1974. Water plants of the world: a manual for the identification of the genera of freshwater macrophytes. Berlin, Springer Science \& Business Media.

Cowardin LM, Carter V, Golet FC, LaRoe ET. 1979. Classification of wetlands and deepwater habitats of the United States. Washington, Department of the Interior, Fish and Wildlife Service.

Crow GE. 1993. Species diversity in aquatic angiosperms: latitudinal patterns. Aquatic Botany 44: 229-258.

Crow GE, Hellquist CB. 2000. Aquatic and wetland plants of northeastern North America: Angiosperms: Monocotyledons (2). Madison, University of Wisconsin Press.

Cunha CN, Junk WJ, Leitão-Filho HF. 2007. Woody vegetation in the Pantanal of Mato Grosso, Brazil: a preliminary typology. Amazoniana 19: 159-184.

Cunha CN, Girard P, Nunes GM, Arieira J, Penha JMF, Junk WJ. 2016. Pantanal - A identidade de uma grande área úmida. In: Peixoto AL, Luz JRP, Brito MA. (orgs.) Conhecendo a biodiversidade. Brasilia, Vozes. p. 14-196.

Drakou EG, Bobori DC, Kallimanis AS, Mazaris AD, Sgardelis SP, Pantis JD. 2009. Freshwater fish community structured more by dispersal limitation than by environmental heterogeneity. Ecology of Freshwater Fish 18: 369-379.

Ferreira FA, Mormul RP, Thomaz SM, Pott A, Pott VJ. 2011. Macrophytes in the upper Paraná river floodplain: checklist and comparison with other large South American wetlands. Revista de Biologia Tropical 59: 541-556.

Foxcroft LC, Pyšek P, Richardson DM, Pergl J, Hulme PE. 2013. The bottom line: Impacts of alien plant invasions in protected areas. In: Foxcroft LC, Pyšek P, Richardson DM, Genovesi P. (eds.) Plant invasions in protected areas. Patterns, problems and challenges. Dordrecht, Springer. p. 19-41.
Goetghebeur P. 1998. Cyperaceae. In: Kubitzki K. (ed.) The families and genera of vascular plants. Volume IV - Flowering Plants Monocotyledons: Alismatanae and Commelinanae (except Gramineae). Berlin/ Heidelberg, Springer. p. 141-190.

Govaerts R, Simpson DA, Goetghebeur P, Wilson KL, Egorova T, Bruhl J. 2016. World Checklist of Cyperaceae. The Board of Trustees of the Royal Botanic Gardens, Kew. http://www. kew.org/wcsp/monocots. 1 Mar. 2016.

Irgang BE, Gastal CVS .1996. Macrófitas aquáticas da planície costeira do RS. Porto Alegre, [s.n.].

Junk WJ. 1986. Aquatic plants of the Amazon system. The Ecology of River Systems 60: 319-338.

Junk WJ, Piedade MTF, Schöngart J, Cohn-Haft M, Adeney JM, Wittmann F. 2011. A classification of major naturally-occurring Amazonian lowland wetlands. Wetlands 31: 623-640.

Junk WJ, Piedade MTF, Lourival R, et al. 2014. Brazilian wetlands: their definition, delineation, and classification for research, sustainable management, and protection. Aquatic Conservation: Marine and Freshwater Ecosystems 24: 5-22.

Keddy PA. 2000. Wetland ecology: Principles and conservation. Cambridge, Cambridge University Press.

Kutschker AM, Beltrán Epele L, Miserendino ML. 2014. Aquatic plant composition and environmental relationships in grazed Northwest Patagonian wetlands, Argentina. Ecological Engineering 64: 37-48.

Lavania, GS, Paliwal SC, Gopal B. 1990. Aquatic vegetation of the Indian subcontinent. In: Gopal B. (ed.) Ecology and management of aquatic vegetation in the Indian subcontinent. The Netherlands, Kluwer Academic Publishers. p. 29-76.

Legendre P, Legendre LF. 2012. Numerical ecology. 2nd. edn. Amsterdam, Elsevier Science.

León B, Young KR, Cano A. 1996. Observaciones sobre la flora vascular de la costa central del Perú. Arnaldoa 4: 67-85.

Maltchik L, Rolon AS, Guadagnin DL, Stenert C. 2004. Wetlands of Rio Grande do Sul, Brazil: a classification with emphasis on plant communities. Acta Limnologica Brasiliensia 16: 137-151.

Morrone JJ. 2009. Evolutionary Biogeography: An Integrative Approach with Case Studies. New York, Columbia University Press.

Morrone JJ. 2014. Biogeographical regionalisation of the Neotropical region. Zootaxa 3782: 1-110.

Moura Júnior EG, Lima LF, Silva SSL, et al. 2013. Aquatic macrophytes of Northeastern Brazil: Checklist, richness, distribution and life forms. Check List 9: 298-312.

Moura Júnior EG, Paiva RMS, Ferreira AC, et al. 2015. Updated checklist of aquatic macrophytes from Northern Brazil. Acta Amazonica 45: 111-132.

Neiff JJ. 2001. Diversity in some tropical wetland systems of South America. In: Gopal B, Junk WJ, Davis JA. (eds.) Biodiversity in wetlands: assessment, function and conservation. Leiden, Backhuys Publishers. p. 157-186.

Oksanen J, Blanchet FG, Kindt R, et al. 2013. Package 'vegan'. Community Ecology Package. Version 2. p. 1-295. Finland, University of Oulu.

Overbeck GE, Müller SC, Fidelis A, et al. 2007. Brazil's neglected biome: the South Brazilian Campos. Perspectives in Plant Ecology. Evolution and Systematics 9: 101-116.

Pivari MOD, Melo PHA, Souza FS, et al. 2018. New initiatives for Brazilian aquatic plant data management. Acta Botanica Brasilica 33: 78-87.

Poff NL. 1997. Landscape filters and species traits: towards mechanistic understanding and prediction in stream ecology. Journal of the North American Benthological Society 16: 391-409.

Pott A, Oliveira AKM, Damasceno-Junior GA, Silva JSV. 2011. Plant diversity of the Pantanal wetland. Brazilian Journal of Biology 71: 265-273.

Pott VJ, Pott A. 1997. Checklist das macrófitas aquáticas do Pantanal, Brazil. Acta Botanica Brasilica 11: 215-227.

Prance GT, Schaller GB. 1982. Preliminary study of some vegetation types of the Pantanal, Mato Grosso, Brazil. Brittonia 34: 228-251.

Pressey RL, Adam P. 1995. A review of wetland inventory and classification in Australia. Vegetatio 118: 81-101. 
R Development Core Team. 2013. R: A language and environment for statistical computing. Vienna, R Foundation for Statistical Computing. http://www.R-project.org/

Ritter NP. 2004. Too wet for aquatic plants? Floristic composition and phytodiversity in the wetlands along the base of the Bolivian Andes. Rhodora 106: 1-32.

Roleček J, Tichý L, Zelený D, Chytrý M. 2009. Modified TWINSPAN classification in which the hierarchy respects cluster heterogeneity. Journal of Vegetation Science 20: 596-602.

Santamaría L. 2002. Why are most aquatic plants widely distributed? Dispersal, clonal growth and small-scale heterogeneity in a stressful environment. Acta Oecologica: 23: 137-154.

Shi JM, Ma KM, Wang JF, Zhao JZ, He K. 2010. Vascular plant species richness on wetland remnants is determined by both area and habitat heterogeneity. Biodiversity and Conservation 19: 1279-1295.
Sieben EJ, Morris CD, Kotze DC, Muasya AM. 2010. Changes in plant form and function across altitudinal and wetness gradients in the wetlands of the Maloti-Drakensberg, South Africa. Plant Ecology 207: 107-119.

Smith AR, Pryer KM, Schuettpelz E, Korall P, Schneider H, Wolf PG. 2008. Fern classification. In: Ranker TA, Haufler $\mathrm{CH}$. (eds.) Biology and evolution of ferns and lycophytes. Cambridge, Cambridge University Press. p. 417-461.

Williams CB. 1964. Patterns in the balance of nature. London, Academic Press.

Zoltai SC, Pollett FC, Jeglum JK, Adams GD. 1975. Developing a wetland classification in Canada. In: Bernier B, Winget CH. (eds.) 4th North American Forest Soils Conference. Canada, Laval University Press. p. 497-511. 